\title{
Superiority of radionuclide over oximetric measurement of left to right shunts
}

\author{
E J BAKER, S V ELLAM, A LORBER, O D H JONES, M J TYNAN, M N MAISEY \\ From the Departments of Paediatric Cardiology, Nuclear Medicine and Clinical Physics, and Bioengineering, Guy's \\ Hospital, London
}

SUMMARY In 100 children with suspected left to right shunts the ratio of pulmonary to systemic flow was measured both by oximetry and first pass radionuclide angiography. The pulmonary time activity curve from the radionuclide study was analysed by the method of gamma variate fits. There was strong correlation between the two techniques; weaker correlation was found when the shunt was at atrial rather than ventricular level. This difference can be explained only by problems with the oximetric rather than the radionuclide technique. Although there are important limitations to the radionuclide method, it is the more precise and less invasive of the two and is to be preferred when the accurate measurement of left to right shunts is required.

The accurate measurement of left to right shunts is essential in the management of many patients with congenital heart anomalies. In clinical practice this is usually performed oximetrically during cardiac catheterisation. The oximetric method is known to have major drawbacks, which can lead to substantial errors. ${ }^{1}$ These problems are worst with shunts at atrial level, when a truly representative mixed venous blood sample is impossible to obtain.

Although other techniques, based on the indicator dilution principle, are available, they are not widely used. Estimation of the ratio of pulmonary to systemic flow by first pass radionuclide angiography is one such method. ${ }^{2}$

Previous studies ${ }^{3-5}$ have shown strong correlation between results from the radionuclide technique and oximetry but they have not correlated the two methods separately for different cardiac malformations. We use radionuclide angiography routinely in children with a variety of congenital heart malformations including those with left to right shunts at both atrial and ventricular level. Here we present results from 100 patients who underwent both first pass radionuclide angiography and cardiac catheterisation.

Requests for reprints to Dr E J Baker, Department of Paediatrics, Guy's Hospital, London SE1 9RT.

Accepted for publication 21 December 1984

\section{Patients and methods}

We studied 100 children with suspected simple left to right shunts. They were aged 1 week to 19 years (mean 4.51 years). In 81 the radionuclide study and cardiac catheterisation were performed within 24 hours of each other. The greatest time between the two procedures was four months. Patients with a ratio of pulmonary to systemic flow greater than four to one, estimated by either method, were not included in the series. Neither technique is likely to be accurate above this level. The Table lists the diagnosis in each case patient.

\section{RADIONUCLIDE TECHNIQUE}

A first pass radionuclide angiogram was obtained in the anterior projection over 20 seconds. Data were collected on a magnetic disk in either list mode or at 32 frames per second and then reframed at two frames per second for analysis. A compact, rapid, bolus of autologous red blood cells labelled with technetium$99 \mathrm{~m}$ was injected via a cannula in a peripheral vein or a catheter lying in the inferior vena cava. Care was taken to ensure a good quality bolus of the radionuclide, which was flushed in with a large volume of saline ( $20 \mathrm{ml}$ in an adult, $5-10 \mathrm{ml}$ in an infant). The right antecubital fossa was the preferred site for peripheral injection. Sedation was used if necessary in the younger patients. The dose of radionuclide was $430 \mathrm{MBq}(11.6 \mathrm{mCi}) / \mathrm{m}^{2}$. 
Table Results with two techriques for measuring left to right shunts in 100 patients

\begin{tabular}{|c|c|c|c|c|c|c|c|}
\hline \multirow[t]{2}{*}{ Age } & \multirow[t]{2}{*}{ Diagnosis } & \multicolumn{2}{|c|}{ Ratio of pulmonary to systemic flow } & \multirow[t]{2}{*}{ Age } & \multirow[t]{2}{*}{ Diagnosis } & \multicolumn{2}{|c|}{ Ratio of pulmonary to systemic flow } \\
\hline & & Oximetric & Radionuclide & & & Oximetric & Radionuclide \\
\hline $\begin{array}{l}1 \text { week } \\
3 \text { weeks } \\
4 \text { weeks } \\
4 \text { weeks } \\
6 \text { weeks } \\
3 \text { months } \\
3 \text { months } \\
3 \text { months } \\
3 \text { months } \\
3 \text { months } \\
3 \text { months } \\
5 \text { months } \\
5 \text { months } \\
5 \text { months } \\
6 \text { months } \\
6 \text { months } \\
6 \text { months } \\
6 \text { months } \\
7 \text { months } \\
7 \text { months } \\
8 \text { months } \\
9 \text { months } \\
9 \text { months } \\
9 \text { months } \\
9 \text { months } \\
9 \text { months } \\
10 \text { months } \\
11 \text { months } \\
11 \text { months } \\
12 \text { months } \\
12 \text { months } \\
14 \text { months } \\
15 \text { months } \\
15 \text { months } \\
16 \text { months } \\
16 \text { months } \\
16 \text { months } \\
16 \text { months } \\
16 \text { months } \\
16 \text { months } \\
17 \text { months } \\
18 \text { months } \\
19 \text { months } \\
20 \text { months } \\
21 \text { months } \\
21 \text { months } \\
22 \text { months } \\
23 \text { months } \\
2 \text { years } \\
2 \text { years }\end{array}$ & $\begin{array}{l}\text { MS+ASD } \\
\text { VSD } \\
\text { VSD } \\
\text { AVSD } \\
\text { VSD } \\
\text { VSD } \\
\text { VSD } \\
\text { VSD } \\
\text { AS } \\
\text { VSD } \\
\text { MS+ASD } \\
\text { VSD } \\
\text { VSD } \\
\text { VSD } \\
\text { VSD } \\
\text { VSD } \\
\text { VSD } \\
\text { ASD } \\
\text { AVSD } \\
\text { ASD } \\
\text { VSD } \\
\text { VSD } \\
\text { VSD } \\
\text { ASD } \\
\text { ASD+VSD } \\
\text { VSD } \\
\text { VSD } \\
\text { VSD } \\
\text { VSD } \\
\text { VSD } \\
\text { PAPVD } \\
\text { VSD } \\
\text { Normal } \\
\text { VSD } \\
\text { VSD } \\
\text { VSD } \\
\text { VSD } \\
\text { VSD } \\
\text { VSD } \\
\text { ASD } \\
\text { VSD } \\
\text { VSD } \\
\text { ASD } \\
\text { ASD } \\
\text { VSD } \\
\text { AVSD } \\
\text { VSD } \\
\text { AVSD } \\
\text { PS } \\
\text { C } \\
\text { VSD }\end{array}$ & $\begin{array}{l}1.2 \\
2.5 \\
2.1 \\
3.7 \\
3.0 \\
2.2 \\
2.0 \\
2.1 \\
1.0 \\
2.2 \\
1.0 \\
3.0 \\
2.2 \\
2.6 \\
2.7 \\
1.8 \\
2.9 \\
1.6 \\
2.5 \\
1.8 \\
2.2 \\
2.4 \\
1.6 \\
2.6 \\
2.3 \\
1.6 \\
1.0 \\
1.1 \\
3.0 \\
3.4 \\
1.9 \\
2.9 \\
1.0 \\
2.6 \\
2.0 \\
2.8 \\
1.8 \\
1.5 \\
2.1 \\
2.2 \\
2.7 \\
1.5 \\
3.4 \\
1.4 \\
2.1 \\
2.5 \\
1.2 \\
1.8 \\
1.0 \\
1.0\end{array}$ & $\begin{array}{l}1.9 \\
2.4 \\
2.5 \\
4.0 \\
3.1 \\
2.3 \\
2.3 \\
2.7 \\
1.0 \\
1.8 \\
1.5 \\
2.2 \\
2.1 \\
2.4 \\
2.4 \\
1.8 \\
2.8 \\
2.4 \\
1.4 \\
1.8 \\
1.9 \\
2.5 \\
1.4 \\
2.6 \\
2.2 \\
2.1 \\
1.3 \\
1.3 \\
2.9 \\
2.9 \\
2.2 \\
3.3 \\
1.2 \\
2.5 \\
2.1 \\
3.2 \\
2.4 \\
1.8 \\
2.0 \\
3.3 \\
2.3 \\
1.5 \\
3.0 \\
1.7 \\
2.2 \\
4.0 \\
1.6 \\
1.9 \\
1.0 \\
1.0\end{array}$ & $\begin{array}{l}2 \text { years } \\
2 \text { years } \\
2 \text { years } \\
2 \text { years } \\
2 \text { years } \\
2 \text { years } \\
2 \text { years } \\
2 \text { years } \\
2 \text { years } \\
2 \text { years } \\
3 \text { years } \\
3 \text { years } \\
3 \text { years } \\
3 \text { years } \\
3 \text { years } \\
3 \text { years } \\
4 \text { years } \\
4 \text { years } \\
4 \text { years } \\
4 \text { years } \\
5 \text { years } \\
5 \text { years } \\
6 \text { years } \\
6 \text { years } \\
6 \text { years } \\
6 \text { years } \\
6 \text { years } \\
8 \text { years } \\
8 \text { years } \\
8 \text { years } \\
9 \text { years } \\
9 \text { years } \\
9 \text { years } \\
10 \text { years } \\
10 \text { years } \\
10 \text { years } \\
10 \text { years } \\
11 \text { years } \\
11 \text { years } \\
11 \text { years } \\
12 \text { years } \\
12 \text { years } \\
13 \text { years } \\
14 \text { years } \\
16 \text { years } \\
16 \text { years } \\
18 \text { years } \\
18 \text { years } \\
18 \text { years } \\
19 \text { years }\end{array}$ & $\begin{array}{l}\text { VSD } \\
\text { VSD } \\
\text { VSD } \\
\text { VSD } \\
\text { AS } \\
\text { ASD } \\
\text { AVSD } \\
\text { VSD } \\
\text { VSD } \\
\text { ASD } \\
\text { ASD } \\
\text { VSD } \\
\text { ASD } \\
\text { ASD } \\
\text { ASD } \\
\text { ASD } \\
\text { VSD } \\
\text { VSD } \\
\text { VSD } \\
\text { VSD } \\
\text { ASD } \\
\text { AI } \\
\text { C } \\
\text { AS } \\
\text { AS } \\
\text { ASD } \\
\text { ASD } \\
\text { AS } \\
\text { VSD } \\
\text { ASD } \\
\text { VSD } \\
\text { ASD } \\
\text { BPS } \\
\text { VSD } \\
\text { VSD } \\
\text { ASD } \\
\text { ASD } \\
\text { VSD } \\
\text { AS } \\
\text { ASD } \\
\text { ASD } \\
\text { PS } \\
\text { VSD } \\
\text { PS } \\
\text { AS } \\
\text { PS } \\
\text { AVSD } \\
\text { VSD } \\
\text { VSD } \\
\text { VSD }\end{array}$ & $\begin{array}{l}1.3 \\
2.5 \\
1.0 \\
1.6 \\
1.0 \\
1.5 \\
3.8 \\
1.1 \\
2.8 \\
1.7 \\
2.0 \\
1.2 \\
1.5 \\
2.0 \\
1.7 \\
2.2 \\
1.6 \\
1.7 \\
1.6 \\
1.3 \\
1.0 \\
1.0 \\
1.0 \\
1.0 \\
1.0 \\
1.7 \\
2.5 \\
1.0 \\
1.1 \\
3.0 \\
1.3 \\
2.0 \\
1.0 \\
2.2 \\
3.5 \\
1.1 \\
1.9 \\
1.4 \\
1.0 \\
2.3 \\
2.4 \\
1.0 \\
2.2 \\
1.0 \\
1.0 \\
1.0 \\
1.5 \\
2.0 \\
1.8 \\
1.8\end{array}$ & $\begin{array}{l}1.2 \\
2.4 \\
1.4 \\
1.9 \\
1.0 \\
1.5 \\
3.0 \\
1.9 \\
2.3 \\
2.5 \\
1.5 \\
1.3 \\
2.1 \\
2.0 \\
2.1 \\
2.0 \\
1.6 \\
2.1 \\
1.5 \\
1.3 \\
1.9 \\
1.0 \\
1.4 \\
1.0 \\
1.0 \\
2.0 \\
2.2 \\
1.0 \\
1.8 \\
2.3 \\
1.6 \\
1.4 \\
1.0 \\
2.3 \\
3.5 \\
1.5 \\
1.7 \\
1.7 \\
1.0 \\
3.0 \\
2.2 \\
1.0 \\
2.2 \\
1.0 \\
1.0 \\
1.0 \\
1.3 \\
1.8 \\
1.7 \\
2.1\end{array}$ \\
\hline
\end{tabular}

MS, mitral stenosis; ASD, atrial septal defect; VSD, ventricular septal defect; AVSD, atrioventricular septal defect; PAPVD, partial anomalous pulmonary venous drainage; PS, pulmonary stenosis; AS, aortic stenosis; AI, aortic incompetence; C, coarctation; BPS, branch pulmonary stenosis.

\section{OXIMETRIC TECHNIQUE}

During investigative cardiac catheterisation performed under sedation blood samples were taken from the superior vena cava, the inferior vena cava, the main pulmonary artery, and a systemic artery. They were taken in rapid sequence when the patient was judged to be in a stable physiological state. The percentage oxygen saturation in each sample was measured spectrophotometrically with a reflectance oximeter. ${ }^{67}$

\section{DATA PROCESSING}

A background corrected, superior vena cava, time activity curve was used to assess the adequacy of the bolus in the radionuclide study. Of those patients eligible for inclusion in the study, six were rejected because the bolus was split. In those in whom the bolus was judged to be of good quality the time activity curve from a region of interest drawn over the right lung was analysed by the method of gamma variate fits. ${ }^{3-5}$ If the bolus was wider than roughly two 


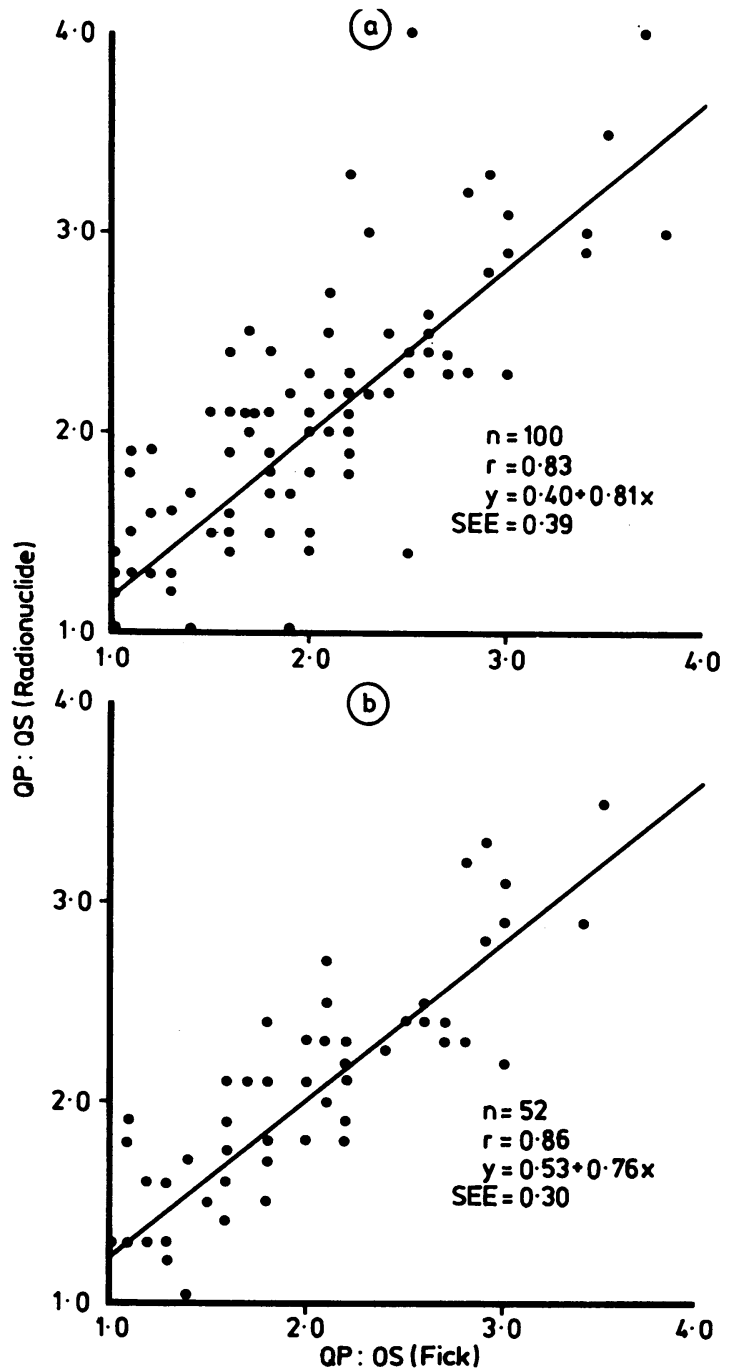

seconds deconvolution analysis was used to correct the pulmonary time activity curve before the shunt analysis was performed. ${ }^{89}$

The pulmonary to systemic flow was calculated from the oximetric data by a formula derived from the Fick principle:

$$
\frac{\mathrm{Q}_{\mathrm{p}}}{\mathrm{Q}_{\mathrm{g}}}=\frac{\text { systemic arterial } \mathrm{SO}_{2} \text {-mixed venous } \mathrm{SO}_{2}}{\text { pulmonary venous } \mathrm{SO}_{2} \text {-pulmonary arterial } \mathrm{SO}_{2}}
$$

( $\mathrm{SO}_{2}$ being oxygen saturation). The mixed venous oxygen saturation was estimated from those in the superior and inferior vena cava (SVC and IVC) by the formula:

$$
\text { Mixed venous } \mathrm{So}_{2}=\frac{3 \times \mathrm{SVC} \mathrm{SO}_{2}+\mathrm{IVCSO}_{2}}{4}
$$

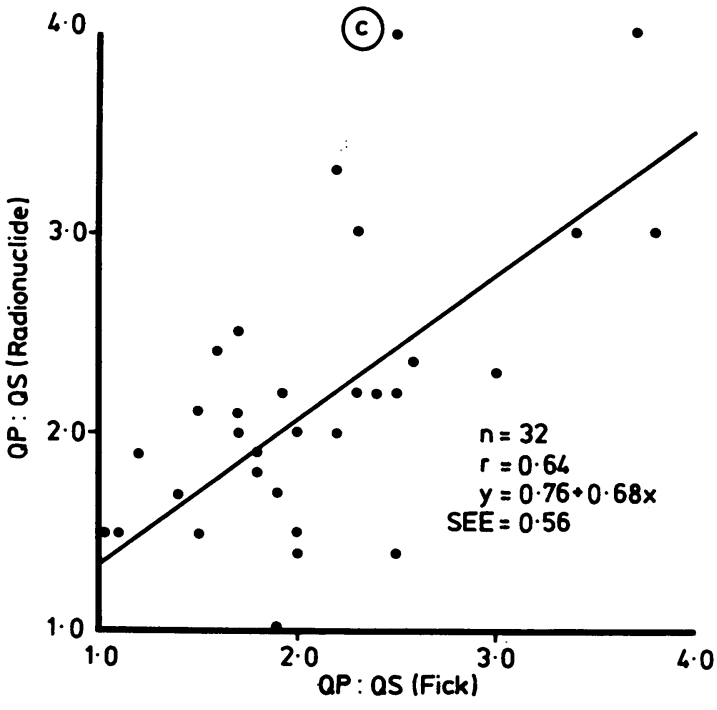

Fig 1 Correlation between oximetric and radionuclide measurement of ratio of pulmonary to systemic flow (QP:QS) in (a) all patients studied; (b) patients with a ventricular septal defect; (c) patients with an atrial left to right shunt. (SEE = standard error of the estimate.)

This formula has been shown to give the most reliable estimate of the true mixed venous oxygen saturation under similar circumstances. 1

\section{STATISTICAL ANALYSIS}

The pulmonary to systemic flow ratios measured by the two techniques were compared by linear regression analysis. The population variances of separate correlations were tested for identity by the $F$ relation. The null hypothesis was rejected when $\mathbf{p}<0.05$.

\section{Results}

The table shows the results for all the patients. Although the correlation for all 100 patients was 
strong, the correlation coefficient ( $r$ ) 0.83 , and the regression coefficient 0.81, Fig. la (scattergram) shows that some points were widely scattered around the regression line. Included in the 100 patients were 16 with no shunt measurable by either technique. The data were then analysed separately for two groups. The first consisted of all patients (52) with a ventricular septal defect and the second of all those with a left to right shunt at atrial level. Patients in the second group included those with atrial septal defects or atrioventricular septal defects and one patient with partial anomalous pulmonary venous connection: 32 patients in all.

The correlation for patients with a ventricular septal defect was strong $(r=0.86)$. The scatter of points was much less than the overall correlation (Fig. 1b). The correlation for shunts at atrial level was weaker $(r=0.64)$, and this group (group 2) contained all the most widely scattered points (Fig. 1c). Although the regression equations for the two groups were similar, there was a significant difference between the population variances $(F=3.44, p<0.001)$.

\section{Discussion}

Our results confirm the validity of the measurement of the ratio of pulmonary to systemic flow by first pass radionuclide angiography in patients with a simple left to right shunt. The correlation remained strong in ventricular shunts even when those patients with no shunt and those with shunts greater than four to one were not included. The strength of the correlation was not therefore dependent on the two ends of the regression relation being fixed. ${ }^{35}$ Previous studies have shown a wide scatter between the radionuclide and oximetric methods in atrial septal defects, ${ }^{10} 11$ but the contrast with the much narrower confidence limits in ventricular septal defects has not previously been shown.

The poorer correlation between the oximetric and radionuclide measurements and the greater population variance when the shunt was at atrial rather than ventricular level cannot be explained by a failing in the radionuclide technique: no additional assumptions are made when the shunt is at atrial level and the acquisition and analysis are identical to that with ventricular shunts. There are problems, however, with the oximetric technique when there is shunting at atrial level. The mixed venous oxygen saturation cannot be measured directly in the presence of a left to right shunt; it has to be estimated from the saturations in the superior and inferior vena cava. The result is inevitably an approximation. The formula we used for this has been shown to give the most reliable estimate of the pulmonary arterial oxygen saturation in patients with no shunt. ${ }^{1}$ When there is an atrial shunt the sites of venous sampling are not separated by the tricuspid valve from the inflow of oxygenated blood. The estimation of the true mixed venous oxygen saturation may under these circumstances be impossible.

Other problems exist with the oximetric technique, whatever the level of the shunt. Notably, in applying the Fick principle the patient is assumed to be in a stable physiological state throughout the time of sampling. There is an appreciable spontaneous variation in the cardiac output at rest in man, ${ }^{12}$ which is likely to introduce considerable inaccuracies, especially if there is any delay between the taking of blood samples at various sites. There are also inaccuracies in the spectrophotometric measurement of the oxygen saturation of blood; it is recognised to be especially inaccurate above $95 \%$ saturation. ${ }^{67}$ These problems have been well discussed elsewhere. ${ }^{1}$

In view of these considerations we believe that first pass radionuclide angiography offers the more accurate of the two measurements of the ratio of pulmonary to systemic flow in patients with simple left to right shunts.

Nevertheless, the radionuclide technique has some important limitations. Previous authors have rightly emphasised the importance of ensuring a good quality bolus in every study. ${ }^{35} \mathrm{We}$ used an injection technique similar to that of Askenazi et al. ${ }^{3} \mathrm{We}$, however, preferred the antecubital fossa as the site for venous cannulation and used sedation routinely in the youngest children to ensure that they were calm and in a stable condition during the study. The data must be processed by an experienced operator. As with all curve fitting techniques, unreliable results can easily be obtained by the inexperienced. With meticulous attention to the performance of the study and its analysis, we found that in virtually every case a valid measurement of the pulmonary to systemic flow could be obtained.

There are also some important considerations that make the radionuclide technique invalid in a minority of patients. The left to right shunt is measured as a proportion of the total pulmonary flow, and from this, assuming there is no appreciable right to left shunt, the pulmonary to systemic flow can be calculated. Findings are therefore invalid when shunting is occurring in two directions. A true measure of the pulmonary to systemic flow ratio can be obtained only when there is a pure left to right shunt or when right to left shunting is negligible, as in atrial septal defects.

In patients with no shunt curves can often be fitted that generate a measurement of the pulmonary to systemic flow ratio of 1.2 to 1 , or less. This has been noted before, and it has been suggested that it is at least partly due to bronchial arterial and chest wall blood flow. ${ }^{3}$ It is probably mostly due to the limitations of the curve fitting method and the statistical 


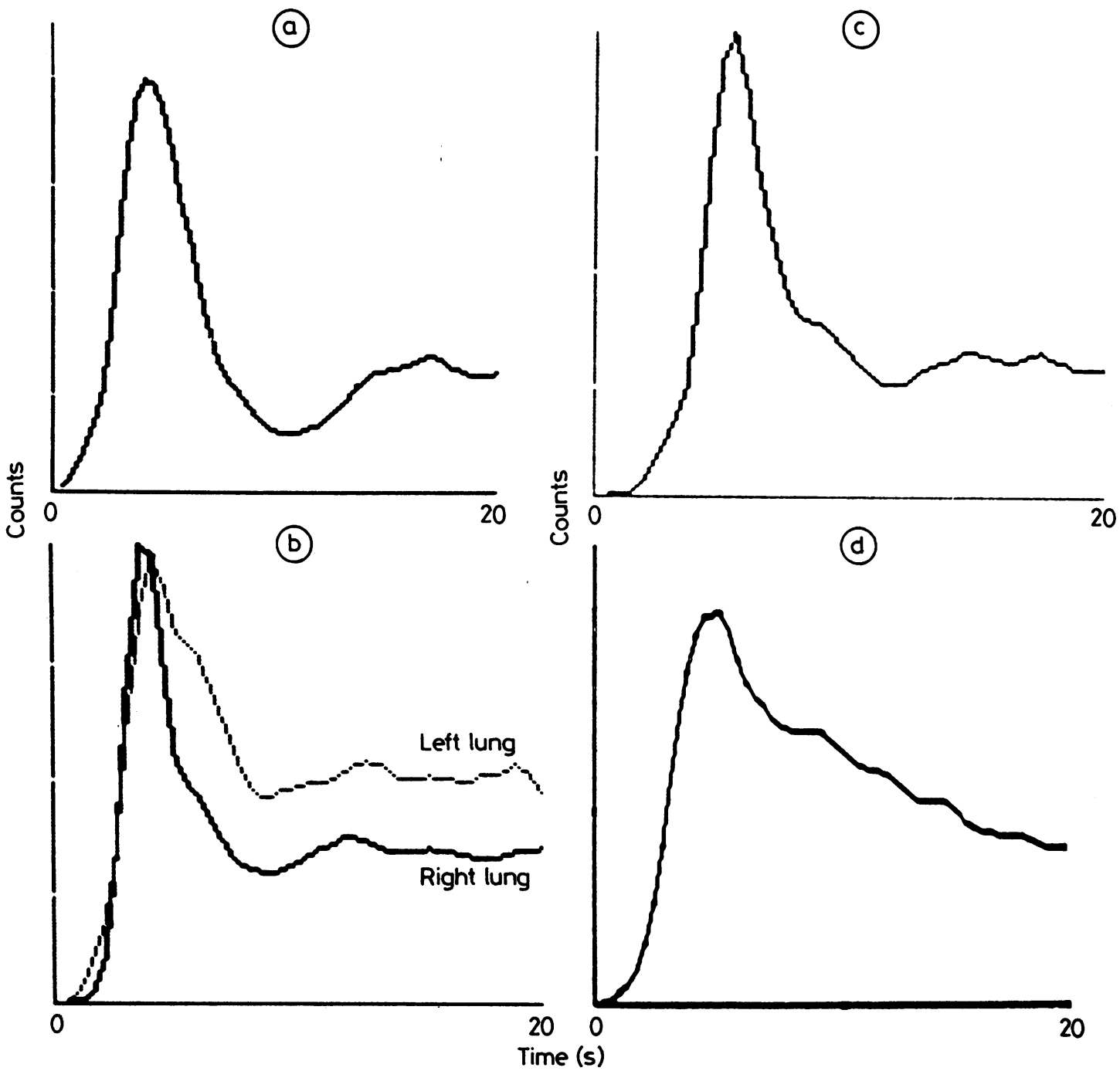

Fig 2 Time activity curves. (a) A normal curve from a right lung region of interest; the patient had mild pulmonary incompetence. (b) Curves from right and left lungs in a patient with a persistent ductus arteriosus. (c) Curve from right lung of a patient with coarctation of the aorta but no shunt. (d) Curve from right lung in a patient with severe postoperative mitral incompetence. Oximetrically the ratio of pulmonary to systemic flow was 1.3:1; analysis of this curve suggested, incorrectly, that it was much greater.

noise present in the data. When the pulmonary time activity curve is unequivocally normal (Fig 2a) we do not attempt curve fitting. Using this policy we have never missed an important left to right shunt. Indeed, as previously reported ${ }^{13}$ the radionuclide technique is more sensitive than oximetry at picking up very small left to right shunts.

With the radionuclide technique, as with oximetry, the overall pulmonary to systemic flow ratio cannot be measured when the lungs are not totally perfused from one central source. This is seen most commonly with a persistent ductus arteriosus but is also applicable when part of the lung is supplied by a major aortopulmonary collateral artery or when there is a patent surgical systemic pulmonary shunt. With a persistent ductus arteriosus the shunt measured from the left lung is. often greater than that measured from the right, as Fig $2 b$ shows. ${ }^{3}{ }^{13}$ Neither is a valid measurement of the overall pulmonary to systemic flow ratio, and it is not valid to take a mean of the two measurements: Despite this, previous authors have included such patients in correlative studies between 
the two techniques. $3-51013$

Patients with coarctation of the aorta may have collateral arteries from the proximal to the distal aorta that cross the lung fields producing a time activity curve that gives the false impression of a left to right shunt, as in Fig $2 c^{2}$ We have noted this even in young infants. It is therefore possible mistakenly to diagnose a left to right shunt or overestimate the magnitude of one when coarctation of the aorta is present.

When cardiac function is very poor or there is severe valvular regurgitation the pulmonary transit time is prolonged, and this may lead to overestimation of the size of the shunt by the radionuclide technique. $^{245}$ Fig 2d illustrates such a case. Under similar circumstances results must be interpreted with extreme caution.

Despite these limitations of the technique the results presented here show its superiority over oximetric measurement in patients with atrial shunts. First pass radionuclide angiography can be performed in outpatients and in critically ill patients at their bedside. The study causes no haemodynamic disturbance and is minimally invasive. It is valid in all age groups. In practice it is probably the most accurate available estimate of the ratio of pulmonary to systemic flow for patients with a simple left to right shunt at any level. Radionuclide angiography should be used to estimate the ratio of pulmonary to systemic flow whenever its accurate measurement is clinically required.

EJB is supported by the British Heart Foundation.

\section{References}

1 Miller HC, Brown DJ, Miller GAH. Comparison of formulae used to estimate oxygen saturation of mixed venous blood from caval samples. Br Heart $\mathcal{F} 1974$; 36: 44651.

2 Anderson PAW, Jones RH, Sabiston DC Jr. Quantita- tion of left-to-right cardiac shunts with radionuclide angiography. Circulation 1974; 49: 512-6.

3 Askenazi J, Ahnberg DS, Korngold E, LaFarge CG, Maltz DL, Treves S. Quantitative radionuclide angiocardiography: detection and quantitation of left to right shunts. Am f Cardiol 1976; 37: 382-7.

4 Alderson PO, Jost RG, Strauss AW, Boonvisut S, Markham J. Radionuclide angiocardiography. Improved diagnosis and quantitation of left-to-right shunts using area ratio techniques in children. Circulation 1975; 51: 113643.

5 Mcllveen BM, Höschl R, Murray IPC, et al. Radionuclide quantitation of left-to-right shunts in children. Aust NZ F Med 1978; 8: 500-8.

6 Holling HE, Macdonald I. O'Halloran JA, Venner A. Reliability of a spectrophotometric method of estimating blood oxygen. F Appl Physiol 1955; 8: 249-54.

7 Polani ML, Hehir RM. New reflectance oximeter. Review of Scientific Instruments 1960; 31: 401-3.

8 Alderson PO, Douglass KH, Mendenhall KG, et al. Deconvolution analysis in radionuclide quantitation of left-to-right cardiac shunts. $f$ Nucl Med 1978; 20: 502-6.

9 Ellam SV, Wright JGC, Maisey MN. Pitfalls in using deconvolution analysis of left to right shunts using first pass radioangiography. Nuclear Medicine Communications 1983; 4: 35-9.

10 Hurwitz RA, Treves S, Keane JF, Girod DA, Caldwell RL. Current value of radionuclide angiocardiography for shunt quantification and management in patients with secundum atrial septal defect. Am Heart $\mathcal{f}$ 1982; 103: 421-5.

11 Ginzton LE, French W, Mena I. Combined contrast echocardiographic and radionuclide diagnosis of atrial septal defect: accuracy of the technique and analysis of erroneous diagnoses. Am $\mathcal{F}$ Cardiol 1984; 53: 1639-42.

12 Barratt-Boyes BG, Wood EH. The oxygen saturation of blood in the venae cavae, right heart chambers, and pulmonary vessels of healthy subjects. $f$ Lab Clin Med 1957; 50: 93-106.

13 Mcllveen BM, Murray IPC, Giles RW, et al. Clinical application of radionuclide quantitation of left to right cardiac shunts in children. Am $\mathcal{F}$ Cardiol 1981; 47: 1273-8. 